\title{
Stanislav Rakús - jubileum medzi textom a jeho teóriou
}

\section{Viera Žemberová (Prešov)}

V novom miléniu sa slovenský literárny život obohatil generačne aj autorsky novátorskými pohybmi pri zobrazovaní príbehu, teda témy a motívu, čo znamená, že sa prínosne sústredil na experimenty pri prelínaní sa umeleckej tvorby s prítomnou mediálnou zobrazovacou výzvou. Azda najvýraznejšie sa spoločenská zmena prejavila v kultúrnej praxi a v aktívnych prejavoch literárneho života pri profilovaní miesta spisovatel'a v spoločnosti, a to sa spojilo s premenou pri hodnotovom presadení sa spoločenského nazerania na status tvorcu, zvlášt medzi spisovatel'mi a literárnymi vedcami nastupujúcej generácie.

Spisovatel' a umelec získali na vážnosti a význame svojho spoločenského prejavu aj vo výraze prejavenej tvorivej slobody. Signálom na vertikalizovanie statusu tvorcu sa stala nielen jeho prirodzená invencia voči podnetom, ktoré sú mu tematikou a problémom na zobrazenie v umeleckom texte blízke, ale aj vo vztahu k nazeracej a estetickej hodnote literárneho diela, napokon sa spoločnost̉ a kultúrna prax spontánne sústredili na jeho nadčasovú „užitočnost"“.

V kultúrnych spoločenstvách, v ktorých sa možno pochválit výraznými udalostami v umeleckej spisbe, sa to tak koná oddávna napríklad udel'ovaním ocenení. Slovenský literárny život, jeho početné komponenty zastúpené spolkami, sponzormi, časopismi, vydavatel’stvami tak činia zverejňovaním viacerých neprehliadnutel'ných umeleckých a literárnych ocenení. Udelovanie spoločnostou prejaveného uznania aj ako, či predovšetkým rešpektu voči talentu tvorcu, tvorbe a jedinečnému prínosu do kultúry, sa pri takto zameranej spoločenskej priazni sústred’uje spravidla pozornost̉ na vopred známe kritériá, ktoré do seba zahrnú očakávané aj neprenosné umelecké a poznávacie i nazeracie hodnoty autorského artefaktu.

Spoločenská a kultúrna hodnota umeleckého diela sa zosúlad’uje s intenzitou tradície, ale reaguje aj na generačné ambície a názorové postoje, a to znamená, že sa pri ujasňovaní si prínosnosti umeleckého a literárnovedného textu dostáva k slovu čoraz naliehavejšie vnímanie záujmu o autorskú výpoved' v širokej kultúrnej a čitatel’skej verejnosti.

Vážnost̉ spomedzi viacerých kultúrnych a umeleckých uznaní, cien, laureátstiev si spoločenský hodnotový rešpekt z autorskej dielne Stanislava Rakúsa získali v roku 2004 Cena Dominika Tatarku za Nenapisaný román, v tom istom roku a za rovnaký literárny text mu udelili Cenu Asociácie organizácií spisovatel’ov Slovenska, a každoročná sútaž prozaických textov, ktoré vyšli v predchádzajúcom roku, v nej získal ocenenie Anasoft litera v roku 2009 za text Telegram. Oceneniami ako prejavom uznania jedinečnej autorskej tvorbe, popri d’alších a početných prekladoch do inonárodných literatúr, môže 
sa pochválit emeritný univerzitný profesor, literárny vedec a prozaik Stanislav Rakús (20. 1. 1940 v Š́rovciach).

Tvorivá amplitúda prozaickej tvorby Stanislava Rakúsa kopíruje tematikou spoločenské pohyby, ktorými prešli česká a slovenská literatúra od začiatku devätdesiatych rokov minulého storočia. A to znamená, že týmto desat’ročím sa dá viest’ deliaca čiara medzi tým, ako sa mení téma a príbeh v Rakúsovej próze. Začínal v šesṫdesiatych rokoch tak, ako to býva zvykom, poviedkami uverejnenými v dobových slovenských a českých periodikách. Po Rakúsovom autorskom prijatí čitatel'skou a odbornou verejnostou jeho poetiky a uvažovania o štruktúre umeleckého textu sa uvádza do dobového literárneho života krehkými, psychologicky a mravne ladenými prózami, v ktorých sa vyrovnáva so sociálnymi a vztahovými kontrastmi, ktoré do života jednotlivca aj rodiny vnáša vášeň sprevádzaná láskou a nenávistou, nespravodlivostou a nenávistou, sociálnou skrivodlivostou a osudovou vypudenostou z najbližšieho spoločenstva.

Emotívne a psychologicky precízne vyrozprávanými príbehmi žien a mužov sa na hrane dobra a zla, nevedomosti a krutosti, žičlivosti a chamtivosti, samoty a osamelosti odvíja pred čitatel’om rozprávanie o tom, ako sa zložito utvárajú a ešte namáhavejšie overujú tie hodnoty, ktoré sú dožičené jednotlivcovi v nel’ahkom živote aj v jeho konečnosti.

Čitatelia si z prvého obdobia znova a znova žiadajú reedície Rakúsových próz Žobráci (1976), o krutých životných skúsenostiach dvoch bratov, Pieseň o studničnej vode (1979), napokon práve $\mathrm{z}$ tohto prozaického súboru sa viaceré texty stali podnetom na televízne a rozhlasové spracovanie, nejeden spomedzi recitátorov na Hviezdoslavovom Kubíne sútažil s niektorým z príbehov z tohto štylisticky a poetikou sugestívneho súboru. Ked' vyšla Mačacia krajina (1986), oslovil Stanislav Rakús príbehmi kocúra Paniberka mladých čitatel'ov, ale azda výraznejšie ich rodičov podobenstvom na existenciu a fungovanie dobrej a harmonickej rodiny, na také vlastnosti v kultivovanej spoločnosti, ako sú dobro, obetavost', pomoc, ústretovost’ a spravodlivost'. Udalosti z konca osemdesiatych rokov minulého storočia vytvorili pre Rakúsovu prozaickú tvorbu novú látkovú a tematickú príležitost'. Autor si zvolil podnety uchované vo svojej profesijnej a spoločenskej pamäti, aby ich vydal a tematizoval v tituloch Temporálne poznámky (1993), Nenapisaný román (2004), Excentrická univerzita (2008). Práve tento titul má na prebale zvýraznenú informáciu, že román je laureátom Ceny Dominika Tatarku. Rakúsovo vyrovnávanie sa so súčasnostou pokračuje prozaickými súbormi Telegram (2009) a Fáza uvol’nenia (2013). Aktuálne rozpracovaný literárny text má pracovný názov Lútost', a ako autor naznačuje, žánrovo sa venuje poviedke.

Spisovatel' Stanislav Rakús zmenil a rozšíril, ale predovšetkým sprítomnil svoju tematiku a neopustil nič z mravných hodnôt, ktoré prostredníctvom humorných aj ironických, ale vždy hĺbavých príbehov, takých či tých postáv, ktoré môžu byt a žit aj v našom susedstve, nechal ožit vo svojich prózach. Spisovatel' očakáva od svojho čitatela , že emóciou, vôlou a empatiou prejaví voči každému jedincovi porozumenie a bude si vážit výnimočný dar života. Súčasne by si mal uchovat porozumenie voči prehreškom vyvolávajúcim aj či nielen úsmev a cibrit' si porozumenie pre všetko, čo je l’udské a čo neničí jedinečný dar, žit' a tvorit život vôkol seba napriek zlu a krutosti.

Literárnovedný výskum Stanislava Rakúsa operuje a pohybuje sa nuansovo v podloží výrazného autorského literárneho textu spravidla z minulého storočia; pozornost̉ venuje 
slovenskej a inonárodnej prozaickej tvorbe. Rakúsove výstupy obsahujú publikácie Próza a skutočnost' (1982), Epické postoje (1988), Medzi mnohoznačnostou a presnostou (1993), v reedíciách vydaná a vyhladávaná publikácia Poetika prozaického textu (1993), esejisticky ladené $Z$ rozprávaní, úvah a rozhovorov (2003), Medzi látkou a témou (2011) a Text a dielo z roku 2019.

Jubilujúci Stanislav Rakús vždy pozorne vážil ním vyslovené slovo, jeho význam aj interpretáciu. Najskôr preto nemožno obíst̉ bez premýšlania ponad jeho rozložité autorské a literárnovedné dielo ním nie tak nedávno vyslovenú takmer sentenciu, ňou sa vedome vymedzuje voči skutočnosti a literárnemu umenia: „považujem sa za sochársky typ autora“.

prof. PhDr. Viera Žemberová, CSc.

Filozofická fakulta, Prešovská univerzita v Prešove

17. novembra č. 1, 08078 Prešov, SK

viazember@gmail.com

This work can be used in accordance with the Creative Commons BY-SA 4.0 International license terms and conditions (https://creativecommons.org/licenses/by-sa/4.0/legalcode). This does not apply to works or elements (such as image or photographs) that are used in the work under a contractual license or exception or limitation to relevant rights. 
